\title{
PEMBERIAN EKSTRAK BUAH JUWET (Syzygium cumini L.) TERHADAP JUMLAH DAN MORFOLOGI SPERMATOZOA TIKUS PUTIH (Rattus Sp.) JANTAN YANG TERPAPAR ASAP ROKOK
}

\section{THE EFFECT OF FRUIT EXTRACTS JUWET (Syzygium cumini L.) ON THE NUMBER AND MORPHOLOGY OF SPERMATOZOA WERE SUPERBLY EXPOSED TO SMOKE}

\author{
Fitria Dwijayanti', A.A.S.A. Sukmaningsih, Ni Made Rai Suarni, Sang Ketut Sudirga' Ni Made Susun Parwanayoni \\ Program Studi Biologi F. MIPA Universitas Udayana \\ ${ }^{1}$ Email : fitriadwijayanti63@yahoo.com
}

\section{INTISARI}

Telah dilakukan penelitian yang bertujuan untuk mengetahui pengaruh ekstrak buah juwet terhadap jumlah dan morfologi spermatozoa yang telah terpapar asap rokok. Dalam penelitian ini digunakan tikus putih jantan umur 3 bulan berat 200-210 gram sebanyak 24 ekor, terdiriatas 4 perlakuan yaitu : kontrol $\left(\mathrm{K}_{0}\right)$, paparan asap rokok $\left(\mathrm{K}_{1}\right)$, ekstrak buah juwet (Syzygium cumini L.) $\left(\mathrm{K}_{2}\right)$, paparan asap rokok dan ekstrak buah juwet $\left(\mathrm{K}_{3}\right)$. Tiap perlakuan terdiri atas 6 kali ulangan. Sebelum perlakuan tikus diaklimatisasi selama 7 hari. Cara pemberian ekstrak buah juwet menggunakan metode gavage sebanyak $2 \mathrm{ml}$ diberikan sekali sehari selama 48 hari sedangkan control diberikan larutan CMC-Na 0,5\%. Paparan asap rokok diberikan sebanyak 1 batang rokok kretek dan dinyalakan dengan bantuan Aerator pump, sekali sehari selama 48 hari. Variabel yang diamatiyaitujumlahdan morfologi spermatozoa. Data dianalisadengan ANOVA dan bila berbeda nyata $(\mathrm{p}<0,05)$ dilanjutkan dengan uji DMRT. Hasil penelitian menunjukkan bahwa jumlah morfologi spermatozoa abnormal berbeda nyata $(\mathrm{P}<0,05)$. Rata-rata jumlah morfologi abnormal pada kelompok $\mathrm{K}_{1}$ lebih tinggi dibanding kelompok $\mathrm{K}_{3}$. Jumlah spermatozoa tidak berbeda nyata antar perlakuan. Nilai rata-rata jumlah spermatozoa $\mathrm{K}_{1}$ lebih rendah dibandingkan $\mathrm{K}_{3}$.Hal ini dikarenakan paparan asap rokok menyebabkan pembentukan $R O S$ yang mengakibatkan stress oksidatif dan menyebabkan kerusakan sel, jaringan dan organ khususnya sistem reproduksi. Ekstrak buah juwet mampu meningkatkan jumlah dan morfologi spermatozoa normal tikus putih yang telah terpapar asap rokok. Hal ini dikarenakan senyawa antioksi dan pada buah juwet dapa tmelindungi sel dari serangan radika lbebas.

Kata kunci: Rattus sp, asap rokok, buah juwet, spermatozoa, ROS, antioksidan.

\section{ABSTRACT}

The research to determine the effect of fruit extracts juwet on the number and morphology of spermatozoa were superbly exposed to smoke has been conducted. This study uses rats aged 3 month, 200-210 gram, total 24 rats consisting of 4 treatment, is control, smoke of cigarette, juwet fruit extracts, and smoke of cigarette to juwet fruit extracts. Each treatment consisting 6 replications, each consisting of 1 rat. Before, acclimatization of rat treated 7 days. Way of giving juwet fruit extracts the gavage method $2 \mathrm{ml}$ once daily for 48 days, while the CMC-Na $0,5 \%$ is given control. The exposure to cigarette smoke is given from an aerator pump, to given once daily for 48 days. Data were analyzed with ANOVA, if they were $5 \%$ significantly different would be followed by a DMRT. The result showed that the number of abnormal sperm morphology were significantly diferent $(\mathrm{p}<0,05)$. The averange number of abnormal spermatozoa K1 group was higher than $\mathrm{K}_{3}$ group. The number of spermatozoa was not significant different between treatments. The average number of spermatozoa $\mathrm{K}_{1}$ lower than $\mathrm{K}_{3}$. This is because the smoke of cigarette increased formation of ROS and the resulting stress oxidative and cause cell damage tissues and organs, especially to the reproductive system. Juwet fruits extract have been able to improve the count and morphologyof rats spermatozoa expose to smoke. This case because of antioxidant from juwet fruit can be protect cell from the free radical attack.

Keywords: Rattus sp, smoke of cigarette, java plum fruit, spermatozoa, , ROS, antioxidant.

\section{PENDAHULUAN}

Rokok merupakan hasil olahan tembakau yang menggunakan bahan tambahan atau pun tidak menggunakan bahan tambahan. Rokok kretek merupakan olahan tembakau dengan bahan tambahan berupa cengkeh (Sukmaningsih, 2009). Asap rokok yang dihirup oleh perokok aktif maupun pasif mengandung gas, partikel ataupun senyawa-senyawa berbahaya seperti karbondioksida, karbon monoksida, oksida dari nitrogen, senyawa hidrokarbon, nikotin, tar, cadium, dan fenol. Senyawa-senyawa tersebut dapat menimbulkan gangguan kesehatan dan peningkatan jumlah radikal bebas di dalam tubuh (Sitohang dkk, 2015). Peningkatan jumlah radikal bebas melebihi kapasitas antioksidan endogen di dalam tubuh untuk menetralisirnya menyebabkan terjadinya stres oksidatif (Winarto, 2010). Radikal bebas atau Reactive Oxygen Spesies (ROS) didefinisikan sebagai suatu molekul, atom, atau beberapa grup atom yang mempunyai satu atau lebih elektron yang tidak berpasangan pada orbit terluarnya (Muchtadi, 2013). Sumber radikal bebas dapat berasal dari dalam tubuh (endogen) dan dari luar tubuh (eksogen). Radikal bebas eksogen berasal dari makanan, minuman, radiasi, pestisida dan polutan (asap pabrik, asap kendaraan dan asap rokok) (Maslachah dkk, 2008). Reactive Oxygen Spesies (ROS) merupakan salah satu penyebab kerusakan spermatozoa (Pietta, 2000).

Spermatozoa sangat peka terhadap kerusakan yang ditimbulkan oleh ROS (Radical Oxygen Spesies) karena membran sel mengandung banyak asam lemak tidak jenuh dan antioksidan intraseluler tidak cukup untuk melindungi membran sel. Kadar ROS yang tinggi tidak hanya mempengaruhi kerusakan membran dan peroksidasi lipid spermatozoa, ROS yang ditimbulkan 
dari stres oksidatif juga dapat menyebabkan kerusakan DNA spermatozoa seperti integritas DNA yang kemudian akan menyebabkan apoptosis (Sukmaningsih dkk, 2015). Apoptosis merupakan kematian sel yang terjadi melalui perubahan struktural dan memerlukan energi sebagai hasil dari rangsang fisiologis ataupun patologis (Fitria dkk, 2013).

Antioksidan mampu melindungi sel dari radikal bebas dan berperan penting sebagai pelindung sel spermatozoa. Antioksidan banyak terkandung dalam sayur-sayuran dan buah-buahan (Indrayana, 2008). Salah satu buah yang mengandung antioksidan adalah buah juwet (Syzygium cumini L.). Aktivitas antioksidan yang dimiliki oleh buah juwet sangat tinggi dan dipengaruhi dari tingkat kematangannya (Kusbandhono, 2011).

Berdasarkan hal tersebut dilakukan penelitian mengenai pengaruh ekstrak buah juwet (Syzygium cumini L.) terhadap morfologi dan jumlah spermatozoa tikus putih jantan (Rattus sp.) yang telah terpapar asap rokok. Tujuan dari penelitian ini adalah untuk mengetahui pengaruh ektrak buah juwet (Syzygium cumini L.) terhadap morfologi dan jumlah spermatozoa tikus putih jantan (Rattus sp.) yang telah terpapar asap rokok.

\section{MATERI DAN METODE}

Sejumlah 24 ekor tikus putih jantan berusia sekitar 3 bulan dengan berat 200-210 gram digunakan sebagai hewan coba. Tikus dibagi dalam 4 kelompok perlakuan dengan 6 kali ulangan. Sebelum pemberian perlakuan hewan diaklimatisasi selama seminggu menggunakan bak plastik yang dialasi dengan sekam dan ditutup dengan penutup kawat serta diberi pakan berupa konsentrat CP551 dan diberi minum secara adlibitum. Kelompok $\mathrm{K}_{0}$ (kontrol) adalah kelompok tikus yang hanya diberikan aquades dan larutan CMC-Na $0,5 \%$. $\mathrm{K}_{1}$ adalah kelompok tikus yang diberi paparan asap rokok. $\mathrm{K}_{2}$ adalah kelompok tikus yang diberi ekstrak buah juwet. $\mathrm{K}_{3}$ adalah kelompok tikus yang diberi paparan asap rokok dan ekstrak buah juwet.

Pembuatan ekstrak buah juwet menggunakan buah dari tanaman juwet (Syzygium cumini L.) yang telah matang, daging buah juwet dipotong kecil-kecil kemudian dikering bekukan (Freeze drying). Sampel kering dimaserasi menggunakan etanol : air $(1: 1)$ selama 60 menit dengan cara diaduk. Proses maserasi dilakukan sebanyak 3 kali sampai warna filtrat bening. Setelah itu hasil maserasi disentrifugasi untuk memisahkan filtrat dengan residu. Kemudian filtrat dievaporasi

Rata-rata jumlah spermatozoa adalah sebagai berikut $\mathrm{K}_{0}=326,33 ; \mathrm{K}_{1}=267,50 ; \mathrm{K}_{2}=309,33 ; \mathrm{K}_{3}=$ 286,17. BerdasarkananalisisdenganujiOne Way ANOVA nilai rata-rata jumlah spermatozoa tidak berbeda nyata antar perlakuan (Tabel 1). Nilai rata-rata jumlah spermatozoa tertinggi terdapat pada kelompok $\mathrm{K}_{0}$ dan nilai rata-rata jumlah spermatozoa terendah terdapat pada kelompok $\mathrm{K}_{1}$. Pada kelompok $\mathrm{K}_{2}$ dan $\mathrm{K}_{3}$ terjadi peningkatan jumlah spermatozoa dibanding kelompok $\mathrm{K}_{1}$ (Gambar 1).

Rata-rata jumlah morfologi spermatozoa abnormal adalah $\mathrm{K}_{0}=18,00 ; \mathrm{K}_{1}=12,67 ; \mathrm{K}_{2}=3,50 ; \mathrm{K}_{3}=$ 7,83 . Nilai rata-rata jumlah morfologi spermatozoa menggunakan vacum rotary evaporator pada suhu $40^{\circ} \mathrm{C}$ sampai volume tertentu. Setelah dievaporasi didapat hasil berupa ekstrak kasar yang berbentuk seperti pasta. Ekstrak kasar tersebut dilarutkan menggunakan CMC-Na $0,5 \%$ dan ekstrak siap digunakan (Sari dkk, 2005). Ekstrak diberikan dengan dosis $360 \mathrm{mg} / 200$ grBB secara oral menggunakan jarum gavage sebanyak $2 \mathrm{ml}$ perhari selama 48 hari.

Paparan asap rokok diberikan setiap hari sebanyak 1 batang rokok kretek dengan kandungan tar $39 \mathrm{mg}$ dan nikotin 2,3 mg untuk 1 ekor tikus dengan menggunakan metode pengasapan hewan coba yang dilakukan menggunakan kotak kaca yang diberi alas sekam dan diberi penutup kaca. Di bagian kanan dan kiri diberi lubang dengan diameter $2 \mathrm{~cm}$ yang berfungsi sebagai ventilasi dan tempat untuk memasukkan batang rokok. Agar rokok tetap menyala pangkal rokok dihubungkan dengan aerator pump melalui selang dengan diameter yang sesuai dengan diameter rokok. Pengasapan dilakukan sampai rokok habis yaitu selama \pm 20 menit. Setelah rokok habis, tikus dibiarkan di dalam kotak pengasapan \pm 15 menit atau sampai asap di dalam kotak hilang. Kemudian hewan coba dikeluarkan dan diletakkan kembali ke dalam kotak pemeliharaan. Paparan asap rokok diberikan selama 48 hari.

Pada hari ke-49, tikus dibedah kemudian diambil kauda epididimisnya untuk membuat suspensi spermatozoa. Pemeriksaan morfologi spermatozoa dapat diamati dengan membuat apusan spermatozoa menggunakan suspensi spermatozoa dan diberi pewarna eosin $1 \%$. Pemeriksaan morfologi ditekankan pada kelainan bentuk atau abnormalitas spermatozoa. Bentuk spermatozoa dianggap abnormal jika terdapat satu atau lebih bagian spermatozoa yang cacat (kepala, leher dan ekor). Hasil dinyatakan dalam persen (Wibisono, 2010).

Pemeriksaan jumlah spermatozoa dapat diamati dengan cara suspensi spermatozoa diteteskan pada hemositometer dan diamati dibawah mikroskop dengan perbesaran 400 kali. Jumlah dinyatakan dengan satuan juta per kauda epididimis (Wibisono, 2010).

Data yang diperoleh dianalisa dengan Analysis of Variance (ANOVA), apabila data menunjukkan berbeda nyata $(\mathrm{p}<0,05)$ maka dilanjutkan dengan uji Duncan Multi Range Test (DMRT) menggunakan program SPSS versi 22.0 tahun 2014.

\section{HASIL}

normal adalah $\mathrm{K}_{0}=82,00 ; \mathrm{K}_{1}=87,33 ; \mathrm{K}_{2}=96,50 ; \mathrm{K}_{3}=$ 92,17 (Tabel 1). Berdasarkan analisis dengan uji One Way ANOVA, nilai rata-rata morfologi spermatozoa abnormal pada kelompok $\mathrm{K}_{1}$ berbeda nyata dengan kelompok $\mathrm{K}_{3}$. Nilai rata-rata morfologi spermatozoa abnormalK $\mathrm{K}_{2}$ berbeda nyata dengan kelompok $\mathrm{K}_{0}$ dan $\mathrm{K}_{1}$. Sedangkan nilai rata-rata morfologi spermatozoa normal pada kelompok $\mathrm{K}_{0}$ berbeda nyata antar perlakuan. Nilai rata-rata morfologi normal kelompok $\mathrm{K}_{1}$ berbeda nyata dengan kelompok $\mathrm{K}_{0}$ dan $\mathrm{K}_{2}$. Nilai rata-rata morfologi spermatozoa normal pada kelompok $\mathrm{K}_{2}$ berbeda nyata dengan kelompok $\mathrm{K}_{0}$ dan $\mathrm{K}_{1}$. (Tabel 1). 


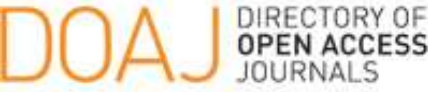

Tabel 1. Hasil rataan dan standar deviasi morfologi dan jumlah spermatozoa tikus putih jantan (Rattus sp.) pada kelompok kontrol dan perlakuan setelah pemberian paparan asap rokok dan ekstrak buah juwet (Syzygium cumini L.) selama 48 hari

\begin{tabular}{|c|c|c|c|c|c|}
\hline \multirow{2}{*}{\multicolumn{2}{|c|}{ Variabel }} & \multicolumn{4}{|c|}{ Perlakuan } \\
\hline & & Kontrol $\left(\mathrm{K}_{0}\right)$ & Rokok $\left(\mathrm{K}_{1}\right)$ & Juwet $\left(\mathrm{K}_{2}\right)$ & $\begin{array}{l}\text { RokokdanJuwet } \\
\qquad\left(\mathrm{K}_{3}\right)\end{array}$ \\
\hline \multirow{2}{*}{ Morfologi } & Abnormal & $18,00 \pm 5,87^{\mathrm{c}}$ & $12,67 \pm 5,01^{\text {bc }}$ & $3,50 \pm 1,52^{\mathrm{a}}$ & $7,83 \pm 4,22^{\mathrm{ab}}$ \\
\hline & Normal & $82,00 \pm 5,87^{\mathrm{a}}$ & $87,33 \pm 5,01 \mathrm{a}^{\mathrm{b}}$ & $96,50 \pm 1,52^{\mathrm{c}}$ & $92,17 \pm 4,22^{\mathrm{bc}}$ \\
\hline \multicolumn{2}{|c|}{$\begin{array}{l}\text { Jumlah Spermatozoa } \\
\text { (juta per kauda epididimis) }\end{array}$} & $326,3 \pm 56,86^{\mathrm{a}}$ & $267,50 \pm 49,60^{\mathrm{a}}$ & $309,33 \pm 51,12^{\mathrm{a}}$ & $286,17 \pm 45,48^{\mathrm{a}}$ \\
\hline
\end{tabular}

Keterangan : huruf superskrif yang berbeda pada baris menunjukkan hasil yang berbeda nyata $(\mathrm{p}<0,05)$ antara kelompok perlakuan, sedangkan huruf superskrif yang sama menunjukkan hasil yang tidak berbeda nyata $(\mathrm{p}>0,05)$, pada uji taraf $5 \%$

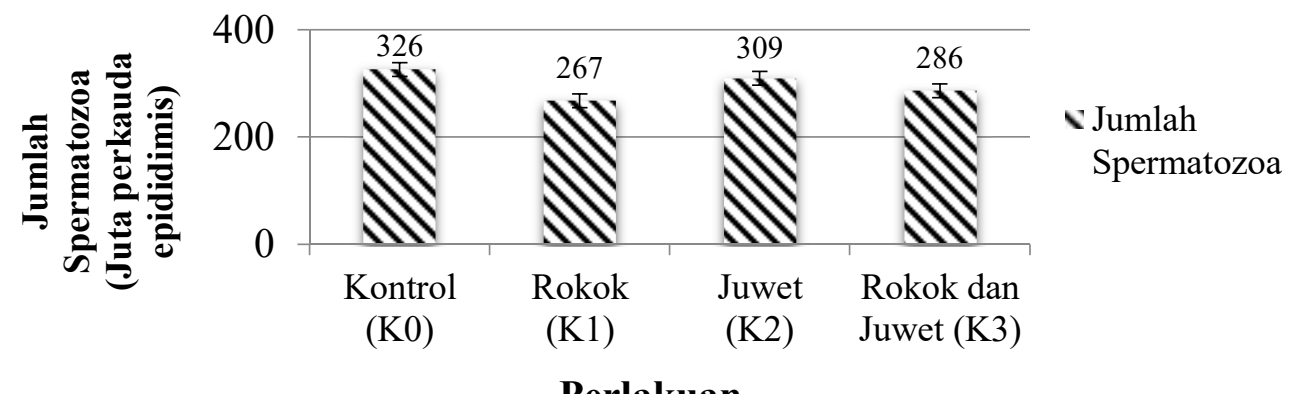

Gambar 1. Diagram rata-rata jumlah spermatozoa tikus putih jantan (Rattus sp.) kelompok kontrol dan perlakuan setelah diberikan paparan asap rokok dan ekstrak buah juwet (Syzygium cumini L.)

Nilai rata-rata jumlah morfologi spermatozoa abnormal pada kelompok $\mathrm{K}_{2}$ mengalami penurunan dibandingkan dengan kelompok $\mathrm{K}_{0}, \mathrm{~K}_{1}$ dan $\mathrm{K}_{3}$. Nilai ratarata jumlah morfologi spermatozoa abnormal pada kelompok $\mathrm{K}_{1}$ mengalami peningkatan dibanding kelompok $\mathrm{K}_{2}$ dan $\mathrm{K}_{3}$, namun mengalami penurunan rata- rata jumlah morfologi spermatozoa abnormal dibanding kelompok $\mathrm{K}_{0}$. Sedangkan nilai rata-rata jumlah morfologi normal pada kelompok $\mathrm{K}_{2}$ mengalami peningkatan dibanding kelompok $\mathrm{K}_{0}, \mathrm{~K}_{1}$ dan $\mathrm{K}_{3}$. Kelompok $\mathrm{K}_{0}, \mathrm{~K}_{1}$ dan $\mathrm{K}_{3}$ mengalami penurunan jumlah morfologi spermatozoa normal dibanding $\mathrm{K}_{2}$ (Gambar 2).

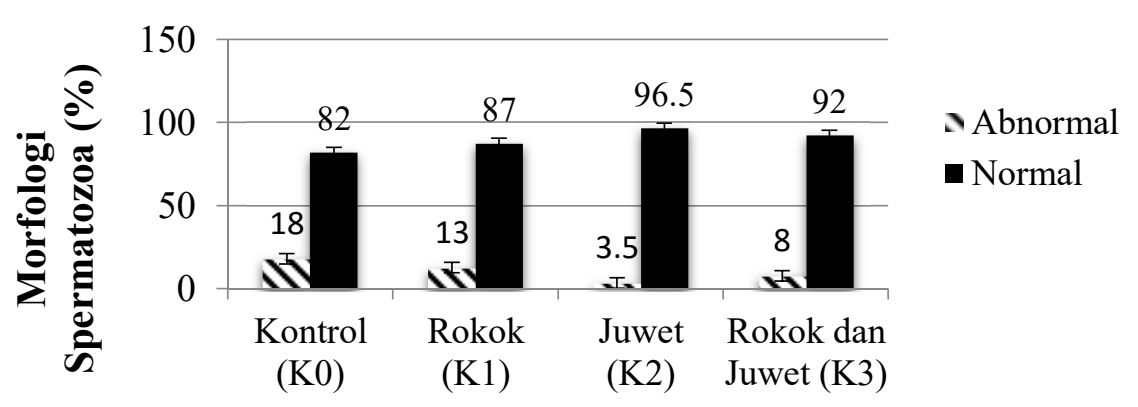

Perlakuan

Gambar 2. Diagram rata-rata morfologi spermatozoa tikus putih jantan (Rattus sp.) kelompok kontrol dan perlakuan setelah diberikan paparan asap rokok dan ekstrak buah juwet (Syzygium cumini L.)

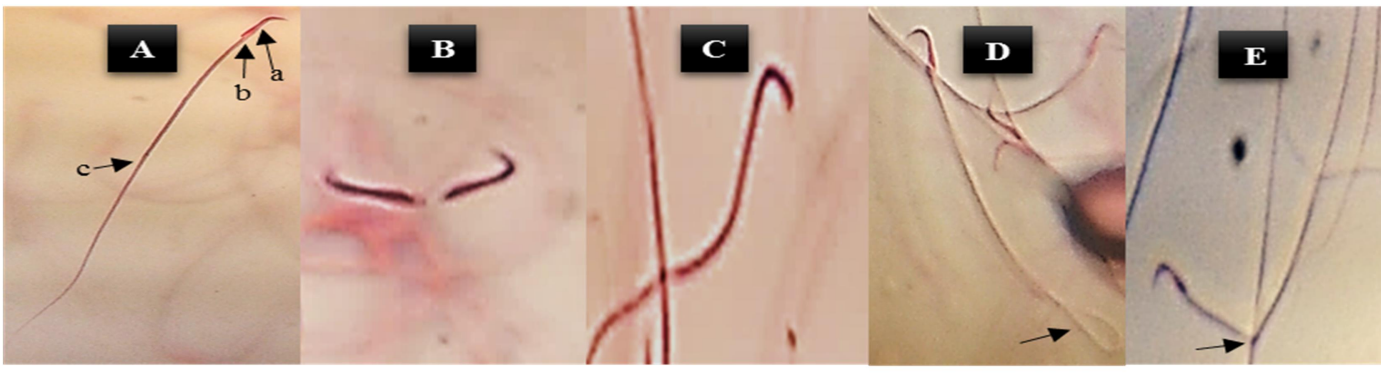

Gambar3. Morfologi spermatozoa (perbesaran 400 kali)

Keterangan gambar:

A. Spermatozoa normal; (a) kepala, (b) leher dan (c) ekor.

B.Spermatozoa tanpa ekor

C. Spermatozoa tanpakepala

D. Spermatozoa ekormelingkar

E. spermatozoa ekor patah membentuk sudut $90^{\circ}$ 


\section{PEMBAHASAN}

Berdasarkan analisis dengan uji lanjut menggunakan Duncan Multi Range Test (DMRT) jumlah spermatozoa tidak berbeda nyata antar perlakuan (Tabel 1). Namun, rata-rata jumlah spermatozoa antar perlakuan berbeda-beda (Gambar 1). Jumlah spermatozoa terendah terdapat pada kelompok $\mathrm{K}_{1}$, hal ini diduga karena paparan asap rokok menyebabkan peningkatan kadar ROS yang dapat memicu terjadinya stres oksidatif. Selain itu, radikal bebas yang terbentuk akibat paparan asap rokok dapat menghambat kerja enzim adenilsiklase pada sel leydig dalam menghasilkan hormon testosteron spermatogenesis dan fungsi epididimis terganggu (Hendri dan Devita, 2015). Terganggunya fungsi epididimis dan spermatogenesis akan menyebabkan penurunan jumlah spermatozoa yang dihasilkan (Solihati dkk, 2013).

Sedangkan pada kelompok $\mathrm{K}_{3}$ mengalami peningkatan jumlah spermatozoa dibandingkan dengan kelompok $\mathrm{K}_{1}$. Hal ini diduga karena pada buah juwet terkandung senyawa antioksidan (eksogen) yang ditandai dengan adanya antosianin sebagai penyebab warna ungu pada buah juwet. Antioksidan pada buah juwet mampu meredam dampak negatif oksidan di dalam tubuh dengan memutus reaksi dari oksidasi berantai radikal bebas (Winarsi, 2007), sehingga jumlah spermatozoa pada kelompok yang diberi ekstrak buah juwet lebih tinggi dibandingkan kelompok yang hanya diberi paparan asap rokok.

Pada penelitian ini terdapat kelainan morfologi spermatozoa abnormalitas primer dan abnormalitas sekunder. Abnormalitas primer yang terlihat yaitu spermatozoa dengan ekor melingkar.Abnormalitas primer terjadi karena pada testis dan saluran reproduksi mengalami degenerasi sel. Hal ini disebabkan karena

\section{UCAPAN TERIMAKASIH}

Ucapan terimakasih kepada Ibu Ni Made Rai Suarni, Bapak Sang Ketut Sudirga, Ibu Ni Wayan Sudatri, Ibu Dwi Ariani Yulihastuti, Ibu A.A.Sg.A. Sukmaningsih K., dan Ibu Ni Made Susun Parwanayoni atas bantuan dan dukungan yang telah diberikan kepada penulis selama penelitian.

\section{DAFTAR PUSTAKA}

Fitria, R.I.N.K., Retno, T., Jabhar, C., Mangimbulude., dan Ferry, F.K. 2013. Merokok dan Oksidasi DNA. Sains Medika. 5(2): 113-120.

Hendri dan Devita. 2015. Efek Rokok Terhadap Kadar Follicle Stimulating Hormone (FSH) dan Luteinizing Hormone (LH) dan Testosteron Pada Pria. Tesis. UPT. Pepustakaan Universitas Andalas.

Indrayana, R. 2008. Efek Antioksidan Ekstrak Etanol $70 \%$ Daun Salam (Syzygium polyanthum [Wight] Walp.) Pada Serum Darah Tikus Putih Jantan galur Wistar yang Diinduksi Karbon Tetraklorida $\left(\mathrm{CCl}_{4}\right)$. Skripsi. Universitas Muhammadiyah. Surakarta. adanya peningkatan kadar ROS yang dapat mempengaruhi membran plasma spermatozoa. Membran plasma spermatozoa banyak mengandung asam lemak tidak jenuh, dimana asam lemak tidak jenuh tersebut sangat rentan terhadap serangan ROS sehingga menyebabkan kerusakan pada spermatozoa (Sitohang dkk, 2015).

Nilai rata-rata spermatozoa abnormal pada kelompok $\mathrm{K}_{0}$ dan $\mathrm{K}_{1}$ setelah diuji menggunakan DMRT tidak berbeda nyata (Tabel 1). Namun, nilai rata-rata dari spermatozoa abnormal pada kelompok $\mathrm{K}_{0}$ lebih tinggi dibandingkan dengan kelompok $\mathrm{K}_{1}$. Hal ini disebabkan karena pada kelompok $\mathrm{K}_{0}$ lebih banyak ditemukan abnormalitas sekunder seperti spermatozoa tanpa kepala, spermatozoa tanpa ekor dan spermatozoa dengan ekor patah membentuk sudut $90^{\circ}$ (Gambar 3). Abnormalitas sekunder terjadi setelah spermiasi, sehingga diduga jumlah spermatozoa abnormal pada kelompok $\mathrm{K}_{0}$ lebih tinggi dibandingkan kelompok $\mathrm{K}_{1}$ karena kesalahan pada saat perlakuan setelah spermatozoa dikeluarkan dari epididimis.

Nilairata-rata spermatozoa abnormal pada kelompok $\mathrm{K}_{1}$ dan $\mathrm{K}_{3}$ tidak berbeda nyata, tetapi rata-rata spermatozoa abnormalitas $\mathrm{K}_{3}$ lebih rendah dibandingkan $\mathrm{K}_{1}$. Hal ini diduga karena pemberian ekstrak buah juwet pada kelompok $\mathrm{K}_{3}$ dapat memperbaiki kerusakan yang disebabkan oleh serangan ROS dengan menangkal radikal bebas.

\section{KESIMPULAN}

Berdasarkan hasil penelitian dapat disimpulkan bahwa pemberian ekstrak buah juwet (Syzygium cumini L.) mampu meningkatkan jumlah spermatozoa dan menurunkan jumlah morfologi spermatozoa abnormal tikus putih (Rattus sp.) jantan yang terpapar asap rokok.

Kusbandhono, E. 2011. Buah Juwet Kaya Zat Antioksidan.

Available at :http://erryk-

kusbandhono.blogspot.com/2011/11

/buah-juwet-buah-yang-kaya-

zat.html

Opened : : 17 Oktober 2013

Maslachah, L., Sugiartuti, R. dan Kurniayanti. 2008. Hambatan Produksi Reactive Oksygen Species Radikal Superoksida $\left(\mathrm{O}_{2}^{-}\right)$Oleh Antioksidan Vitamin E ( $\alpha$ - thocoperol) Pada Tikus Putih (Rattus norvegicus) Yang Menerima Stressor Rejatan Listrik. Departemen Ilmu Kedokteran Dasar Veteriner, Fakultas Kedokteran Hewan, Kampus C Universitas Erlangga. Media Kedokteran Hewan. 24(1): 21-26.

Muchtadi, D. 2013. Pangan dan Kesehatan Jantung. Alfabeta. Bandung.

Pietta, P. G. 2000. Flavonoids as antioxidants.J. Nat. peroxidation. Am. J. Clin. Nutr.61, 549-554. Prod. 63, 1035-1042.

Sari, P., Agustina. F., Komar, M., Unus.,Fauzi, M. dan Lindriati, T. 2005. Ekstraksidan Stabilitas 
Antosianin Dari Kulit Buah Duwet (Syyzygium cumini L.).Jurusan Teknologi Hasil Pertanian FTP Universitas Jember. Jurnal Teknol Dan Industri Pangan.16(2): 143.

Sitohang, A.G., Wantouw, B. dan Queijoe, E.D. 2015. Perbedaan Antara Efek Pemberian Vitamin C Dan Vitamin E Terhadap Kualitas Spermatozoa Tikus Wistar (Rattus norvegicus) Jantan Setelah Diberi Paparan Asap Rokok. Jurusan Biologi Fakultas Kedokteran Unversitas Sam Ratulang Manado. Jurnal e-biomedik (eBm). 3(1): 69-70.

Solihati, N., Purwantara, B., Supriatna, I., dan Winarto, A. 2013. Perkembangan Sel-Sel Spermatogenik dan Kualitas Sperma Pascapemberian Ekstrak Pegagan (Centella asiatica). Fakultas Peternakan Universitas Padjajaran. Bandung. JITV. 18(3): 192-201.

Sukmaningsih, A.A.Sg.A. 2009. Penurunan Jumlah Spermatosit Pakiten dan Spermatid Tubulus Seminiferus Testis Pada Mencit (Mus musculus) yang Dipaparkan Asap Rokok. Jurusan Biologi Fakultas matematika dan Ilmu Pengetahuan Alam
Universitas Uadayana. Bali. Jurnal Biologi. 13(2): 31 .

Sukmaningsih, A.A.Sg.A., N.M. Rai. S., N.W. Sudatri., Triwahyu, P., dan Sitarina, W. 2015. Apoptosis Sel Spermatogenik Pada Tikus Putih (Rattus norvegicus) yang Terpapar Asap Rokok Setelah Pemberian Ekstrak Buah Juwet (Syzygium cumini). Proseding Seminar Nasional Sains dan Teknologi FMIPA Universitas Udayana, Kampus Bukit Jimbaran, Badung. 29-30 Oktober 2015.

Winarto, D. 2010. Pemanfaatan Vitamin C dan E Sebagai Antioksidan Untuk Memperbaiki Kuantitas dan Kualitas Spermatozoa.

Available at:

http://www.umpwr.ac.id/artikel/477-pemanfaatanvitamin-c-dan-e-sebagai-antioksidan-untukmemperbaiki-kuantitas-dan-kualitas-spermatozoa.html Opened : 17 Oktober 2013

Wibisono, H. 2010. Panduan Laboratorium Andrologii. PT Refika Adiatma. Bandung.

Winarsi, H. 2007. Antioksidan Alami dan Radikal Bebas. Penerbit Kanisius. Yogyakarta. 